\title{
Association Study of Grain Yield and Nutritional Quality Traits in Pearl Millet [Pennisetum glaucum (L.) R. Br.] Hybrids
}

\author{
K. Subbulakshmi ${ }^{1^{*}}$, P. Sumathi ${ }^{2}$ and C. Babu ${ }^{3}$ \\ ${ }^{1}$ Centre for Plant Breeding and Genetics, ${ }^{2}$ Department of Millets, ${ }^{3}$ Department of Forage \\ crops, TNAU, Coimbatore-3, Tamil Nadu, India \\ *Corresponding author
}

\section{A B S T R A C T}

\begin{tabular}{|c|}
\hline Keywords \\
\hline $\begin{array}{l}\text { Biofortification, } \\
\text { Correlation, Path } \\
\text { analysis, Grain yield, } \\
\text { Pearl millet }\end{array}$ \\
\hline Article Info \\
\hline $\begin{array}{l}\text { Accepted: } \\
\text { 15 September } 2018 \\
\text { Available Online: } \\
10 \text { October } 2018\end{array}$ \\
\hline
\end{tabular}

\section{Introduction}

Pearl millet is an important coarse grain cereal adapted to the arid and semi-arid tropical areas of Africa and the Indian subcontinent with 200-800 $\mathrm{mm}$ annual rainfall, where no other cereal crop can be grown successfully. India is one of the largest producers in Asia. Pearl millet [Pennisetum glaucum (L.) R. Br.] belongs to the family Poaceae (graminae) and genus Pennisetum. It is a highly crosspollinated crop with protogynous flowering and wind borne pollination mechanism, which
Genetics of quality parameters and their associations with grain yield and its component traits have a direct bearing on devising effective strategies for breeding biofortified crop cultivars. A newly developed 54 hybrids of pearl millet showed large genetic variability for yield and nutritional traits. Correlation studies revealed that single plant yield has positive significant correlation with the agronomic traits viz., plant height, number of productive tillers, test weight, single head grain weight and quality traits viz., crude fiber, beta carotene and iron whereas the trait days to fifty per cent flowering alone was recorded negatively significant correlation with single plant yield. It is therefore inferred that simple selection will be effective against positively correlated characters. There is no correlation between grain zinc and yield which suggests that, there is possibility of selection for increased grain zinc content without reducing the grain yield. Maximum direct effect on grain yield was contributed by single head grain weight which is positive and highly significant followed by single head grain weight and number of productive tillers. Results of this present study put forward the way to the development of biofortified cultivars. 
unpredictable as selection indices (Khairwal et al., 1999).

\section{Materials and Methods}

The trial was carried out in randomized block design (RBD) with three replications under the prevailing environmental conditions at department of millets, TNAU, Coimbatore, lies between $11^{\circ}$ North latitude and $77^{\circ}$ East longitude. Each genotype was represented by 3 rows of $5 \mathrm{~m}$ length with $45 \mathrm{~cm}$ between rows and $15 \mathrm{~cm}$ between plants. Till the harvesting, all the recommended inputs and cultural practices including fertilizer, irrigation, hoeing and pest control were followed. The genetic material used in this study was received from Department of Millets, TNAU. A total of fifty four newly developed hybrids were utilized for the present study. Variability analysis was carried out for the newly developed fifty four hybrids for thirteen characters which include eight biometric and five quality traits viz., days to fifty per cent flowering, plant height, number of productive tillers/plant, earhead length, earhead girth, test weight, single head grain weight, single plant yield, crude protein, crude fiber, beta carotene, iron and zinc. The observation was recorded for nutritional traits viz., protein content $(\mathrm{N} \times$ x 6.25) using microkjeldahl method (Jackson 1973). The zinc and iron contents were determined by using Atomic absorption spectrophotometer (Humphries 1956) at the department of environmental sciences, TNAU, Coimbatore. Crude protein and crude fiber content were estimated at the Department of Forage crops, Centre for Plant Breeding and Genetics. All the statistical analysis was done by using TNAUSTAT statistical software.

\section{Results and Discussion}

Results of phenotypic and genotypic correlation for yield and nutritional traits were presented in the table 1. Phenotypic correlation was higher than genotypic correlation for all the characters studied, which shows that environment also plays an important roles for the trait expression.

The traits plant height (0.2379), number of productive tillers per plant (0.6308), test weight $(0.8792)$ and single head grain weight $(0.8401)$ were significantly positive correlation with single plant yield. These results were conformity with the earlier results of Hepziba et al., (1993), Tomer et al., (1995), Poongodi and Palanisamy (1995), Anarase et al., (2001), Khan et al., (2002) and Govindaraj et al., (2009).

In the case of nutritional traits viz., crude fiber (0.2343), beta carotene (0.5065) and iron (0.4107) content also recorded positively significant association with single plant yield and it can be improved without harming the yield. Whereas the character days to fifty per cent flowering (-0.2760) recorded significantly negative correlation with single plant yield. This result has conformity with the previous works of Govil et al., (1982), Izge et al., (2006) and Vetriventhan et al., (2007).

The quality traits viz., crude protein and zinc had no correlation with single plant yield and these findings have similarity with Arya et al., (2009). Contrast results also reported by (Virk, 1988 and Choudhary, 2003) as negative significant correlation of grain yield with quality parameters.

In the case of inter correlation resulted that, association between the traits plant height, earhead length, single head grain weight, crude fibre, beta carotene and iron were positively significant and which indicates that selection for these traits in the early generation will work out. The results were in agreement with findings of Azhaguvel (1997) and Latha and Shanmugasundaram (1998). 
Table.1 Genotypic correlation analysis for thirteen traits of hybrids

\begin{tabular}{|c|c|c|c|c|c|c|c|c|c|c|c|c|c|}
\hline & DFF & PH & NPT & EHL & EHG & TW & SHW & CP & CF & BC & FE & $\mathbf{Z N}$ & SPY \\
\hline DFF & & -0.1286 & $-0.2827 *$ & 0.1210 & 0.0126 & $-0.2963 * *$ & -0.1661 & 0.0683 & -0.1605 & -0.1552 & $-0.3469 * *$ & -0.0773 & $-0.2760 *$ \\
\hline PH & -0.1175 & & $-0.3129 * *$ & $0.6929 * *$ & $0.3814 * *$ & 0.0917 & $0.4756^{* *}$ & -0.1789 & $0.2652 *$ & $0.4192 * *$ & $0.2905^{*}$ & 0.1145 & $0.2379 *$ \\
\hline NPT & $-0.2239 *$ & $-0.2628^{*}$ & & $-0.4809 * *$ & -0.1796 & $0.5792 * *$ & 0.1423 & 0.0366 & 0.0285 & $0.2470^{*}$ & 0.0980 & -0.0949 & $0.6308 * *$ \\
\hline EHL & 0.1933 & $0.6135^{* *}$ & $-0.3514 * *$ & & $0.3557 * *$ & 0.1128 & $0.5482 * *$ & -0.1230 & $0.2379 *$ & $0.3318^{* *}$ & 0.1376 & 0.1762 & 0.1985 \\
\hline EHG & 0.0202 & $0.3324 * *$ & -0.1383 & $0.3073^{* *}$ & & 0.0642 & 0.1534 & $-0.2571 *$ & 0.0166 & $0.2623^{*}$ & 0.1808 & 0.0975 & 0.0950 \\
\hline TW & $-0.2797 *$ & 0.0858 & $0.4943^{* *}$ & 0.1046 & 0.0797 & & $0.6902 * *$ & 0.0033 & $0.2971^{* *}$ & $0.4771 * *$ & $0.3301^{* *}$ & 0.1351 & $0.8792 * *$ \\
\hline SHW & -0.1485 & $0.4436^{* *}$ & -0.0344 & $0.4691 * *$ & 0.1305 & $0.6360 * *$ & & -0.0326 & $0.2392 *$ & $0.3835^{* *}$ & $0.4078 * *$ & $0.2264^{*}$ & $0.8401 * *$ \\
\hline CP & 0.0669 & -0.1733 & 0.0301 & -0.1102 & $-0.2190^{*}$ & 0.0016 & -0.0313 & & -0.0973 & 0.0240 & 0.0389 & 0.0685 & 0.0037 \\
\hline CF & -0.1531 & $0.2569^{*}$ & -0.0265 & 0.2080 & 0.0037 & $0.2926^{*}$ & $0.2282^{*}$ & -0.0964 & & 0.1867 & 0.1207 & 0.0952 & $0.2343^{*}$ \\
\hline BC & -0.1506 & $0.4069^{* *}$ & 0.1957 & $0.2966 * *$ & $0.2305^{*}$ & $0.4622 * *$ & $0.3551 * *$ & 0.0233 & 0.1838 & & $0.2548 *$ & 0.0946 & $0.5065^{* *}$ \\
\hline $\mathbf{F E}$ & $-0.2917^{*}$ & $0.2496^{*}$ & 0.0491 & 0.1060 & 0.1322 & $0.2822^{*}$ & $0.3527 * *$ & 0.0295 & 0.1081 & $0.2282 *$ & 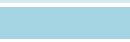 & $0.3609 * *$ & $0.4107 * *$ \\
\hline $\mathbf{Z N}$ & -0.0613 & 0.0931 & -0.0565 & 0.1295 & 0.0664 & 0.1278 & 0.1864 & 0.0622 & 0.0940 & 0.0951 & $0.3201 * *$ & & 0.1496 \\
\hline SPY & $-0.2616^{*}$ & $0.2270 *$ & $0.5575^{* *}$ & 0.1827 & 0.0905 & $0.8685^{* * *}$ & $0.7745^{* *}$ & 0.0036 & $0.2295^{*}$ & $0.4893 * *$ & $0.3588^{* *}$ & 0.1389 & \\
\hline
\end{tabular}

** Significant at 1 per cent level; * Significant at 5 per cent level. Upper diagonal indicates genotypic correlation and down diagonal indicates phenotypic correlation

DFF: Days to fifty per cent flowering, PH: plant height, NPT: Number of productive tillers, EHL: Ear head length, EHG: Ear head girth, TW: Test weight, SWG:

Single head grain weight, CP: Crude protein, CF: Crude fibre, BC: Beta carotene, FE: Iron, ZN: Zinc, SPY: Single plant yield

Table.2 Genotypic path analysis with dependent variables

\begin{tabular}{|c|c|c|c|c|c|c|c|c|c|c|c|c|c|}
\hline & DFF & PH & NPT & EHL & EHG & TW & SHW & CP & CF & BC & FE & $\mathbf{Z N}$ & $\begin{array}{l}\text { Genotypic } \\
\text { correlation }\end{array}$ \\
\hline DFF & 0.0286 & -0.0017 & -0.1384 & 0.0016 & 0.0007 & -0.0327 & -0.1043 & 0.0016 & -0.0079 & -0.0080 & -0.0149 & -0.0004 & $-0.2760 *$ \\
\hline PH & -0.0037 & 0.0132 & -0.1532 & 0.0090 & 0.0201 & 0.0101 & 0.2986 & -0.0041 & 0.0131 & 0.0216 & 0.0125 & 0.0006 & $0.2379^{*}$ \\
\hline NPT & -0.0081 & -0.0041 & 0.4897 & -0.0062 & -0.0095 & 0.0639 & 0.0893 & 0.0008 & -0.0014 & 0.0127 & 0.0042 & -0.0005 & $0.6308 * *$ \\
\hline EHL & 0.0035 & 0.0092 & -0.2355 & 0.0130 & 0.0188 & 0.0124 & 0.3443 & -0.0028 & 0.0117 & 0.0171 & 0.0059 & 0.0010 & 0.1985 \\
\hline EHG & 0.0004 & 0.0050 & -0.0879 & 0.0046 & 0.0528 & 0.0071 & 0.0963 & -0.0059 & 0.0008 & 0.0135 & 0.0078 & 0.0005 & 0.0950 \\
\hline TW & -0.0085 & 0.0012 & 0.2836 & 0.0015 & 0.0034 & 0.1103 & 0.4335 & 0.0001 & 0.0146 & 0.0246 & 0.0142 & 0.0007 & $0.8792 * *$ \\
\hline SHW & -0.0047 & 0.0063 & 0.0697 & 0.0071 & 0.0081 & 0.0761 & 0.6280 & -0.0007 & 0.0118 & 0.0198 & 0.0175 & 0.0012 & $0.8401 * *$ \\
\hline CP & 0.0020 & -0.0024 & 0.0179 & -0.0016 & -0.0136 & 0.0004 & -0.0205 & 0.0229 & -0.0048 & 0.0012 & 0.0017 & 0.0004 & 0.0037 \\
\hline CF & -0.0046 & 0.0035 & -0.0140 & 0.0031 & 0.0009 & 0.0328 & 0.1502 & -0.0022 & 0.0493 & 0.0096 & 0.0052 & 0.0005 & $0.2343^{*}$ \\
\hline BC & -0.0044 & 0.0055 & 0.1209 & 0.0043 & 0.0138 & 0.0526 & 0.2409 & 0.0006 & 0.0092 & 0.0516 & 0.0110 & 0.0005 & $0.5065 * *$ \\
\hline FE & -0.0099 & 0.0038 & 0.0480 & 0.0018 & 0.0095 & 0.0364 & 0.2561 & 0.0009 & 0.0059 & 0.0131 & 0.0430 & 0.0020 & $0.4107 * *$ \\
\hline $\mathrm{ZN}$ & -0.0022 & 0.0015 & -0.0464 & 0.0023 & 0.0051 & 0.0149 & 0.1422 & 0.0016 & 0.0047 & 0.0049 & 0.0155 & 0.0055 & 0.1496 \\
\hline
\end{tabular}

** Significant at 1 per cent level; * Significant at 5 per cent level. Residual effect $=0.218$

DFF: Days to fifty per cent flowering, PH: plant height, NPT: Number of productive tillers, EHL: Ear head length, EHG: Ear head girth, TW: Test weight, SWG:

Single head grain weight, CP: Crude protein, CF: Crude fibre, BC: Beta carotene, FE: Iron, ZN: Zinc, SPY: Single plant yield 
Results of path coefficient analysis are presented in the table 2 . The correlation study measures the relationship between pairs of traits. Whereas, dependent traits are an interaction with mutually associated components. The path analysis takes into account the cause and effect relationship between the variables by partitioning the association into direct and indirect effects through other independent variables. The direct and indirect associations on grain yield were carried out using coefficient of all the traits with grain yield plant per plant. In this study, the response variable grain yield and other twelve variables, path analysis was possible to categorize plant characteristics according to magnitude of their effect on grain yield.

The path analysis revealed that, plant height had moderate positive direct effect followed by crude fiber on grain yield. High positive effect was observed for the traits viz., number of productive tillers per plant and single head grain weight its indirect effect through other observed characters were also positive. It was confirmed by Hepziba et al., (1993) and Poongodi and Palanisamy (1995) for the influence of traits like number of productive tillers. Similarly, days to fifty per cent flowering had positive direct effect, but had negative association with grain yield per plant.

Low positive effect was obtained for the trait test weight which also had positive and highly significant association with single plant yield. From the present study point toward that an ideal pearl millet plant should have significant number of productive tillers, test weight and single head grain weight since they expressed significant correlation with maximum direct effect on grain yield per plant. Selection based on these traits may be helpful in development of efficient breeding programme.

\section{References}

Anarase, S.A., Ugale, S.D. and Shinde, G.C. (2001). Correlation and path-coefficient analysis in pearl millet. The Andhra Agric. J. 48:33-36.

Arya R.K., H.P. Yadav, Desh Raj and Ashok Kumar Yadav. (2009). Correlation studies of white and grey grain colour hybrids in pearl millet. Agric. Sci. Digest, 29(2).

Azhaguvel, P. (1997). Morphological and molecular characterization of cytosteriles in pearl millet (Pennisetum glaucum (L.) R. Br.). M.Sc. (Ag.) Thesis, Tamil Nadu Agric. Univ., Coimbatore.

Chaudhry, M. H., Chaudhry, M.H., S.G. Mahboob, S.M. Saleem and Usman, S. (2003). Correlation and path coefficients analysis in pearl millet (Pennisetum americanum L.). Pakistan J Biol. Sci., 6: 597 -600.

Govil, J.N., S.C. Pokhriyal and B.R. Murty. (1982). Full-sib and reciprocal recurrent selection in relation to pearl millet improvement. Theor. Appl. Genet. 62, 25-30.

Govindaraj, M., B. Selvi and S. Rajarathinam. (2009). Correlationg studies for grain yield components and nutritional quality traits in pearl millet germplasm. World J. Agric. Sci. 5 (6): 686-689.

Hepziba, J.J., R. Saraswathi, M.T. Mani, R. Rajasekaran and S. Palanisamy, 1993. Genetic variability, association among metric traits and path co-efficient analysis in pearl millet. Annals Agric. Res., 14(3): 282-285

Khairwal, I.S., K.N. Rai, D.J. Andrews and G. Harinarayana. (1999). Pearl millet Breeding. Oxford and IBH Pub. Co, New Delhi.

Khan, F.A.K., and K. Sukumar. (2002). Genotypic and Phenotypic correlation and path analysis in napier grass 
Pennisetum purpureum (K) Schum, germplasm. Madras Agric. J. 89 (13):164-166.

Latha, R. and Shanmugasundaram, P. (1998). Combining ability studies involving new male sterile lines in pearl millet. Madras Agric. J., 85(3, 4): 160-163.

Poongodi, J.L. and S. Palanisamy. (1995). Correlation and path analysis in pearl millet (Pennisetum glaucum). Madras Agric. J., 82: 98-100.

Tomer, N.S., Kushawaha, V.S. and Singh, G.P. (1995). Association and path analysis of elite genotypes of pearl millet (Pennisetum typhoides $\mathrm{S}$ and $\mathrm{H}$.). J. Soil Crops, 5(2): 117- 120.

Virk, D.S. (1988) Biometrical analysis in pearl milled - A Veviewd Crop Improv 15:1-29.

\section{How to cite this article:}

Subbulakshmi, K., P. Sumathi and Babu, C. 2018. Association Study of Grain Yield and Nutritional Quality Traits in Pearl Millet [Pennisetum glaucum (L.) R. Br.] Hybrids. Int.J.Curr.Microbiol.App.Sci. 7(10): 2035-2039. doi: https://doi.org/10.20546/ijcmas.2018.710.235 